\title{
Promote Teaching Reform with Innovation Competition
}

\author{
Song Lihong \\ Department of Information Science and Technology \\ Science College \\ Tianjin University of Finance and Economics, China \\ slhapple@126.com
}

\begin{abstract}
Innovation competition is of great significance to the teaching reform and the training of innovative and applied talents. Based on undergraduate teaching of software engineering major, this paper studies the innovation competition system and puts forward the feasible schemes of the teaching reform, including mufti-curriculum cooperation, selecting projects by students themselves, developing extracurricular comprehensive practice, building cloud platform for information sharing, setting up student teams and echelons, normalizing competition and blended teaching. Take "Android program development" course as an example to carry out the teaching reform measures. Practice shows that it is effective to improve student interest and professional quality. It is helpful for students to further study.
\end{abstract}

Keywords - Innovation competition; Teaching Reform; Practice Teaching; Flipped Classroom

\section{RESEARCH BACKGROUND}

Encouraging students to participate in innovation competition is one of the most effective ways to cultivate college students' engineering practice and innovation ability. It is also a good way to promote teaching. But in fact, the effect of innovation competition is not enough currently [1].

In the teaching and practice of software engineering, passive learning and practice is still main stream in specialized and practical courses. The teacher is centered and students in the framework prescribed by the teacher. Students passively complete the study and practice tasks. In the whole teaching process, especially in the course of practice, students' subjective initiative is insufficient. Their thinking, design and participation are not enough [2].

First of all, at present, most practices are still verification experiments. The content of practice is just for the consolidation of knowledge. Design and comprehensive experiments are very few. Secondly, the experimental contents are divorced from the modern software engineering process and lack the design of comprehensive experiments. This leads to the poor effect of practice teaching and the lack of the cultivation of students' innovative ability. It is difficult to cultivate students' creative thinking. Thirdly, the introduction of innovative competition ideas and techniques are very limited in teaching [3].

Therefore, the students need to do a lot of preparatory work before the competition, including planning, learning, and comprehensive application of a number of courses knowledge.
It takes a lot of time. Some students have to give up because preparation time is not enough. Only a few students can win the prize. In fact, classroom teaching and competition are consistent with the training direction and objectives. More students will benefit from the measures of integrating the competition's guidance and ideas into the classroom and incorporating the content of the competition into practice. It will help enlarge the proportion of students participating in the competition and improve the quality of teaching as a whole. Over time, it will gradually form an advantage in profession [4].

\section{The Advantages of InNOVATIVE COMPETITION IN TEACHING}

The competition integrating into all aspects of teaching will improve the students' interest in learning, develop students' knowledge, and make it easy to train students' innovative senses and practical ability. It is beneficial to form students' active practice mode in practice. As students are the main part of the active practice, students take the initiative to complete the practice of all the key steps. This is the key to cultivating innovative consciousness and practical ability in undergraduate teaching. And innovation competition can cultivate students' practical ability [5].

The students are eligible to participate in many national innovation competitions, such as "Internet + college students' innovation Entrepreneurial competition", "the National Mobile Internet Contest", "the Five Provinces in North China and Hong Kong, Macao and Taiwan Students Computer Application Contest" and so on.

From competition requirements and characteristics of past award-winning works, software undergraduate teaching content are demanded to link to real industry demand closely. Students will practice in aspects including function design, algorithm design, development technology, database, network, software testing and deployment and so on. The experience will improve their creative thinking, active research; cultivate the innovative design and engineering practice ability.

Take "the Five Provinces of North China and Hong Kong, Macao and Taiwan students Computer Application Contest " as an example, the competition preparation work are decomposed as shown in table $1[5,6]$. 
TABLE I. THE COMPETITION PREPARATION STEPS

\begin{tabular}{|l|l|}
\hline \multicolumn{1}{|c|}{ Steps } & \multicolumn{1}{c|}{ Work } \\
\hline $\begin{array}{l}\text { Requirement } \\
\text { Analysis }\end{array}$ & $\begin{array}{l}\text { consulting } \\
\text { technical materials } \\
\text { requiring research } \\
\text { selecting topics }\end{array}$ \\
\hline System Design & $\begin{array}{l}\text { system design } \\
\text { core module design } \\
\text { algorithm design } \\
\text { system prototype design }\end{array}$ \\
\hline System Implementation & $\begin{array}{l}\text { code implementation } \\
\text { algorithm optimization }\end{array}$ \\
\hline $\begin{array}{l}\text { Testing } \\
\text { and } \\
\text { deployment }\end{array}$ & $\begin{array}{l}\text { unit testing } \\
\text { integration testing } \\
\text { system testing } \\
\text { deployment of projects }\end{array}$ \\
\hline Presentation & $\begin{array}{l}\text { summarizing project } \\
\text { presentation }\end{array}$ \\
\hline Summary & writing papers or reports \\
\hline
\end{tabular}

It can be seen that the innovation contest tests the ability of students to apply professional knowledge to the design and practice of various fields. In terms of the connotation system, it is more in line with the actual situation of engineering design. The whole competition embodies the practice model of "student oriented, teacher assisted ". The competition experience effectively expands the students' vision and stimulates the students' interests. Students' subjective initiative and creative thinking can be fully developed. Theoretical knowledge has been consolidated by competition. Student's system design ability and hands-on operation ability have been trained by project practice.

\section{TEACHING REFORM MEASURES}

In order to introduce the innovation competition into the undergraduate education system, and make it an important practice teaching link, the following reforms should be carried out for the current teaching.

\section{A. Combine innovative competition with typical practice teaching}

Establish multi-curriculum cooperation, complete the project driven teaching model and build cross curricular projects in the teaching of related courses. Let students feel the real project development process in the school. If the project is too small, the effect is limited. Students are difficult to form a system view.

There are a lots of lessons such as "program design practice", "data structure practice"," database practice", "image processing practice", "web programming practice" and so on. Each practical course completes the teaching practice task separately and the content is not related. Due to lack of project experience, it is very difficult for students to understand the link between the courses as a whole. The teacher integrates existing typical practice teaching into innovative project practice courses and set the content into one integrated project, including requirements, system design, algorithm design and system implementation, testing and deployment etc. The teacher integrates the necessary knowledge and skills into the study of innovative experimental projects. After knowing the concepts and mastering the skills, the students are able to integrate, connect and apply them to solve practical problems. Students are also more likely to understand the connection and application of learning and to enhance their interest in learning and exploration.

\section{B. Encourage students to choose projects independently}

In addition to the necessary verification experiments, the practice of the experiments are designed to be independent subject-oriented, highlighting the characteristics of innovation and practicality. The subject content of the experiment should be close to the actual demand, and guide the students to read the technical materials extensively and enlarge the scope of topics. Teachers can also take award-winning projects as examples. So the students can stand on a higher starting point to design and plan their own projects. They are eager to master new knowledge and skills to solve the internal needs of their projects. The learning efficiency will be significantly improved.

Students are encouraged to make their own design projects, so as to improve their interest in learning, give them full imagination space, and enable them to learn to think and innovate actively.

\section{Develop extracurricular comprehensive practice}

We can build a platform for students to display their talents, arouse students' professional interest, and lay a foundation for the follow-up applying and completion of innovative projects.

Generally speaking, the projects are innovative and difficult. It is difficult to finish in class, so it is necessary to continue studying in spare time.

On one hand, we should open specialized laboratories for students and provide practical experimental environment. On the other hand, teachers need to guide students in the process of comprehensive practice. Teachers have aimed at second classrooms to help them learn new techniques and optimize system design and implementation. By discovering the problems exposed by students, teachers correct the deficiencies in time, improve the guiding methods, update the content of courses, and improve the quality of teaching as a whole.

\section{Build cloud platform for information sharing}

Establish online publishing and retrieval of student practice courses and projects. The platform records the stage results of the students' learning process, stimulates the students' enthusiasm for practice and keeps the students' motivation to keep studying. At the same time, the teacher guides the whole teaching process continuously, controls the whole course and improves the evaluation system of the practical course.

\section{E. Set up student teams and echelons}

Innovation competitions are organized in the form of teams, which require team members to conduct a reasonable division in accordance with their own special skills. Students with different learning styles and skills can play their roles in the project. Encourage senior students to lead low grade students to learn autonomously, and construct student echelon. When the students win high levels of innovation competition and get some achievements, it is a great encouragement for his team. Other students will be easier to arouse the learning enthusiasm. More students will join the team. 


\section{F. Normalize competition}

In different grades, a series of related competitions are designed, making the competition as a part of the teaching plan. Competition in accordance with different grades students can be stratified to basic training, ability improvement and integrated innovation. It will attract the vast majority of students to participate in the competition actively. According to the different interest points, students are encouraged to choose different professional directions, such as information management system, algorithm research, embedded platform, mobile application development, etc.

This greatly arouses the students' professional interest and enthusiasm for learning. That enhances students' innovation consciousness, improves the students' initiative ability, and promotes communication between students. That gradually lays the foundation for the high grade student to participate in national and international competitions.

\section{G. Blended teaching}

As we introduce the competition into the course, the original classroom teaching content expands, but the teaching time is limited. Only when students have certain practice basis they can have the ability to innovate.

Therefore, the existing teacher oriented classroom needs to be transformed into a student oriented practice model. That is Flipped classroom.

The teacher's task has changed. Teachers need to prepare teaching resources before class. Instead of repeating similar lectures every day at school, the teacher's class will communicate with students and help students improve their skills. Students need to watch videos before class and bring problems to class, which greatly improves the students' enthusiasm for learning.

The teacher needs to prepare some teaching materials for the flipped classroom. The current teaching resources are shown in the table2.

So when preparing the course, we follow the rules:

- Select existing high quality course resources as a supplement to micro lectures.

- Don't repeat the procedures in the MOOC curriculum.

- The teacher make videos according to the teaching content, competition demands and topics, corresponding to the actual level of students.

- Design preview assignments and online testing contents to check the students' study.

- Provide further study materials and topics in class.

TABLE II. THE DIFFERENCE OF TEACHING RESOURCES

\begin{tabular}{|l|l|l|}
\hline $\begin{array}{l}\text { Teaching } \\
\text { Resource }\end{array}$ & Content & Characteristics \\
\hline & & $\begin{array}{l}\text { Famous teachers give lectures. } \\
\text { Open to all learners. } \\
\text { MOOC }\end{array}$ \\
& $\begin{array}{l}\text { Massive Open charge. } \\
\text { Online Courses } \\
\text { Learn independently. } \\
\text { Main resources for online learning. }\end{array}$ \\
\hline
\end{tabular}

\begin{tabular}{|l|l|l|}
\hline \multicolumn{2}{|c|}{ Cont. to TABLE II } \\
\hline SPOC & $\begin{array}{l}\text { Small Private } \\
\text { Online Course } \\
\text { Micro-lecture the students in the school or } \\
\text { A major resource for online learning. } \\
\text { A secondary resource or as a resource } \\
\text { for classroom teaching. }\end{array}$ \\
\hline $\begin{array}{l}\text { Take short video as the main carrier. } \\
\text { resource package } \\
\text { Record complete teaching activities } \\
\text { of teachers. } \\
\text { Focus on a certain knowledge point } \\
\text { or teaching link. }\end{array}$ \\
\hline
\end{tabular}

IV. TAKE "ANDROID PROGRAM DEVELOPMENT" COURSE AS AN EXAMPLE.

This course is a main elective course in junior college of software engineering major. Students already have the foundation of Java. The content of the micro lecture is the content of the course in class before. The videos of lectures will be deployed on the server. The students download or watch online. The experiments before become assignments of preview. The table 3 shows the contents of the course.

TABLE III. THE CONTENTS OF ANDROID COURSE

\begin{tabular}{|c|c|c|}
\hline Video of Lecture & Preview Assignments & Contents in Class \\
\hline $\begin{array}{l}\text { 1. introduction and } \\
\text { development } \\
\text { environment of } \\
\text { Android }\end{array}$ & $\begin{array}{l}\text { Download the Software } \\
\text { Development Kit (SDK). } \\
\text { Follow the video and } \\
\text { install SDK. }\end{array}$ & $\begin{array}{l}\text { Solving problems in } \\
\text { installation, such as } \\
\text { version issues, etc. } \\
\text { Discuss the difference of } \\
\text { Android development } \\
\text { tools. }\end{array}$ \\
\hline $\begin{array}{l}\text { 2. Android } \\
\text { Program creation }\end{array}$ & $\begin{array}{l}\text { Create Android Applicati } \\
\text { on. } \\
\text { Install APK to Mobile ph } \\
\text { one Or } \\
\text { Simulator. }\end{array}$ & $\begin{array}{l}\text { Android program } \\
\text { structure. } \\
\text { The role of different files. } \\
\text { Compare the similarities } \\
\text { and differences between } \\
\text { different versions of } \\
\text { Android systems. }\end{array}$ \\
\hline $\begin{array}{l}\text { 3. Android life } \\
\text { cycle }\end{array}$ & $\begin{array}{l}\text { Watch the video. } \\
\text { (It is difficult for students } \\
\text { to understand. No } \\
\text { assignment. ) }\end{array}$ & $\begin{array}{l}\text { Give the examples to } \\
\text { show the states of the } \\
\text { Android Application and } \\
\text { activities step by step. } \\
\text { Guide the students to test } \\
\text { each step of the life cycle. }\end{array}$ \\
\hline $\begin{array}{l}\text { 4. Android user } \\
\text { interface }\end{array}$ & $\begin{array}{l}\text { Follow the video to } \\
\text { design the layout and } \\
\text { controls of activities. }\end{array}$ & $\begin{array}{l}\text { Analyze the familiar APP, } \\
\text { such as Sharing bikes, } \\
\text { Taobao and so on. } \\
\text { Introduce the works of } \\
\text { Prize-winning Student } \\
\text { design. } \\
\text { Present by students to } \\
\text { show their user interfaces. }\end{array}$ \\
\hline 5. Android Service & $\begin{array}{l}\text { Watch the video; } \\
\text { (It is difficult for students } \\
\text { to understand. No } \\
\text { assignment. ) }\end{array}$ & $\begin{array}{l}\text { Principles and } \\
\text { mechanisms of service. } \\
\text { Local Service and remote } \\
\text { Service. } \\
\text { Inter-process } \\
\text { communication. } \\
\text { Take examples such as } \\
\text { downloading large files } \\
\text { requiring updating the } \\
\text { download schedule in UI } \\
\text { thread. }\end{array}$ \\
\hline $\begin{array}{l}\text { 6. Data storage } \\
\text { and access }\end{array}$ & $\begin{array}{l}\text { Watch the video; } \\
\text { Create and access the } \\
\text { database in Android } \\
\text { System. }\end{array}$ & $\begin{array}{l}\text { Emphasis on Database } \\
\text { sharing. } \\
\text { Compare the data storage } \\
\text { in local and Server. } \\
\text { Take typical application, } \\
\text { "phone book" as an } \\
\text { example. }\end{array}$ \\
\hline
\end{tabular}




\begin{tabular}{|c|c|c|}
\hline \multicolumn{3}{|c|}{ Cont. to TABLE III } \\
\hline $\begin{array}{l}\text { 7. Location } \\
\text { services and map } \\
\text { applications }\end{array}$ & $\begin{array}{l}\text { Watch the video. } \\
\text { (It is difficult for students } \\
\text { to understand. No } \\
\text { assignment. ) }\end{array}$ & $\begin{array}{l}\text { Use third party SDK; } \\
\text { How to user Baidu Map } \\
\text { API; } \\
\text { Build Baidu Map } \\
\text { application system based } \\
\text { on Android. }\end{array}$ \\
\hline $\begin{array}{l}\text { 8. Using the HTTP } \\
\text { protocol }\end{array}$ & $\begin{array}{l}\text { Watch the video and Set } \\
\text { up the server using prior } \\
\text { knowledge } \\
(\mathrm{J} 2 \mathrm{EE})\end{array}$ & $\begin{array}{l}\text { Send the HTTP request } \\
\text { from Android Application } \\
\text { in thread. } \\
\text { Asynchronously accept } \\
\text { the response returned by } \\
\text { the server. } \\
\text { Discuss the } \\
\text { communication of APP } \\
\text { and the Server by HTTP; }\end{array}$ \\
\hline $\begin{array}{l}\text { 9. Android } \\
\text { Sensors } \\
\text { Application }\end{array}$ & $\begin{array}{l}\text { Watch the video (It is } \\
\text { difficult for students to } \\
\text { understand. No } \\
\text { assignment. ) }\end{array}$ & $\begin{array}{l}\text { Introduce the different } \\
\text { types and applications of } \\
\text { sensors in Android } \\
\text { system. } \\
\text { Register listeners to } \\
\text { receive callback data by } \\
\text { sensors. } \\
\text { Introduce the application } \\
\text { by sensors such as } \\
\text { Running applications and } \\
\text { so on. }\end{array}$ \\
\hline 10. Design Project & $\begin{array}{l}\text { Contact software } \\
\text { engineering knowledge } \\
\text { and do the requirement } \\
\text { analysis and design of } \\
\text { Android project }\end{array}$ & $\begin{array}{l}\text { Set up student teams. } \\
\text { Present the innovation } \\
\text { ideas of projects by } \\
\text { students. } \\
\text { Discuss the solution of the } \\
\text { projects. } \\
\text { Design the interface of the } \\
\text { projects. }\end{array}$ \\
\hline $\begin{array}{l}\text { 11. Develop the } \\
\text { Android } \\
\text { Application } \\
\text { And Server }\end{array}$ & $\begin{array}{l}\text { Establish Android } \\
\text { program framework. } \\
\text { Establish the Server } \\
\text { Application }\end{array}$ & $\begin{array}{l}\text { Solve the key point of the } \\
\text { project. } \\
\text { Share the ideas of } \\
\text { innovation. } \\
\text { Build threads in Android } \\
\text { and Server. }\end{array}$ \\
\hline $\begin{array}{l}\text { Test the Android } \\
\text { and }\end{array}$ & $\begin{array}{l}\text { Watch the video to learn } \\
\text { how to Deploy the App } \\
\text { on Internet. }\end{array}$ & $\begin{array}{l}\text { Deploy the web server on } \\
\text { cloud platform and test } \\
\text { Android Application in } \\
\text { real world. }\end{array}$ \\
\hline $\begin{array}{l}\text { 13. Test and } \\
\text { iterative develop }\end{array}$ & $\begin{array}{l}\text { Test and develop } \\
\text { iteratively. }\end{array}$ & $\begin{array}{l}\text { Solve the problem } \\
\text { occurring in testing. } \\
\text { Share the experience. }\end{array}$ \\
\hline $\begin{array}{l}\text { 14. Project } \\
\text { Presentation }\end{array}$ & $\begin{array}{l}\text { Prepare for the } \\
\text { presentation }\end{array}$ & $\begin{array}{l}\text { Teacher comments } \\
\text { Student reviews }\end{array}$ \\
\hline
\end{tabular}

In order to ensure that students learn video before class, the video will set problems. Students solve them by assignments. The contents of the class are adjusted accordingly to their level. Students put forward the problems encountered in preparation and teachers to solve problems in class. This greatly increases the amount of information in class and the rate of student absorption. The contents of the course are presented in the micro lectures. Validation experiments are completed as assignments before class. The main point in the class is solving the problem. Extended and in-depth study and practice are completed in class.
We have developed more than one hundred videos for the course of "Android program development". The number of videos is increasing including the basic points, the advanced parts and the competition related contents.

The course assessment methods include online testing, offline programming, and online deployment. The results of the course consist of many stages and scores.

During the past two years, many students have benefited greatly. They learn the basic of the course online during their spare time. Then solve the problem they met. They experience the whole process of project development. They can see the real result of software which is deployed on the server. They can show their work to others. It's especially helpful.

Students with different levels of learning have their own gains. Practice has proved that the blended model of flipped classroom and traditional classroom is more suitable for the course study of software engineering specialty and it can extend the class to a great extent.

\section{CONCLUSION}

The introduction of innovation competition into undergraduate creative education system has promoted the optimization of curriculum, especially the software technology courses, constantly updated the knowledge structure. More and more students benefit from them. More than 10 Students in our major have won the first prize in National Computer Application Contest. After recent years of practice, students' professional interest is stronger and stronger. In addition to academic achievements, graduates have project experience, and have obvious advantages in the process of further study and employment.

\section{REFERENCES}

[1] Li Y G, Wu Y C, Liu XX. The teaching reform and exploration of national quality resource sharing course of electrical machinery[C], International Conference on Electrical Machines and Systems. IEEE, 2017. J. Clerk Maxwell, A Treatise on Electricity and Magnetism, 3rd ed. , vol. 2. Oxford: Clarendon, 1892, pp. 68-73.

[2] Hao Y, Wan S. Research on Teaching System Reform of Fundamental Computer Course[C], Second International Workshop on Education Technology and Computer Science. IEEE Xplore, 2010:456-459. K.

[3] Yang Y. Electronic Design Competition and Practice Teaching Reform[J]. Journal of research and exploration in laboratory, 2013.

[4] Wang Y S, Jiang Y, Lin-Feng H E, Make Innovation on Unique Teaching Method of "Integration of Competition \&Practices" in Combination of Skill Competition-take electric automation technology specialty as an example[J]. Journal of Tianjin Vocational Institutes, 2016.

[5] Li P,Du Exploration of active practice teaching driven by discipline competition[J]. Journal of China Electric Power Education, 2013.

[6] Chen Sh, Reform of Experimental Teaching System for Information Major[J]. Journal of Research and Exploration in Laboratory, 2012. 